\title{
ANALYSIS OF COST EFFICIENCY IN FOOD CROP PRODUCTION AMONG SMALL-SCALE FARMERS IN ADAMAWA STATE, NIGERIA
}

\author{
D. C. MAURICE, Y. ADAMU AND M. JOSEPH
}

(Received 17 October 2014; Revision Accepted 15 November 2014)

\begin{abstract}
Efficient allocation of resources has been a problem in small holder farm economy in Nigeria. The study analyzes cost efficiency in food crop production among small-scale farmers in Adamawa State, Nigeria. Specifically, the socioeconomic characteristics of food crop farmers in the study area were described, their various cropping systems identified and the cost efficiency indices of the farmers determined. Data were collected from 360 randomly selected food crop farmers in eight local government areas spread across the four ADP zones of the State using structured questionnaires. The analytical tools were descriptive statistics involving the use of frequency tables and inferential statistics involving the use of stochastic frontier cost function. The result revealed that married female farmers constituted majority (57.22\%) of the respondents. Their literacy level was high, as $84 \%$ of them had some form of formal education. The respondents cultivated an average of about two hectares of farm land using personal savings. Eleven cropping systems were identified with mixed cropping accounting for about $53 \%$ of the cropping systems and about $54 \%$ of the total hectarage allocations. The maximum likelihood estimates of the stochastic cost function revealed that the explanatory variables; extension contact, crop diversification and credit availability were significantly and positively related to cost efficiency in the study area. The cost efficiency index ranged from $0.18-0.98$, with a mean of 0.84 implying that an average farm in the study area has the scope for increasing cost efficiency by $16 \%$ given the existing technology. The study recommended farmers education on fundamental farm management skills to enable farmers plan, evaluate and appraise their farm business activities among others.
\end{abstract}

KEYWORDS: Cost efficiency, Cropping systems, Small-scale food crop farmers, Adamawa State, Nigeria

\section{INTRODUCTION}

The agricultural sector is an important sector in the Nigerian economy in terms of its role in food security, poverty alleviation and economic growth. Food crop production is a major component of all production activities in that sector and comes under different cropping systems, most commonly as mixed farming, mixed cropping or monocropping due largely to consideration for risk minimization, stable income and adaptability to a particular season (Sani and Haruna, 2010).

Food crop production in Nigeria is dominated by small-scale farmers who cultivate between $0.1-5.99$ hectares and produce about $85-90 \%$ of the total foods consumed in the country (Agbonlahor, 1999; Maurice et al., 2013). These farmers are constrained by inadequate finance to expand production, hence rely on personal savings for their agricultural operations. They are also influenced by farm-specific factors, which delineate their production frontiers resulting in low outputs. Studies have shown that socio-economic characteristics affect farmers' efficiency in production as it influences production decisions, availability and level of use of modern inputs and technology.

When scarce resources are not efficiently utilized by resource poor farmers it could have a multiplier effect on their livelihood and incomes. These farmers would not be able to generate sufficient incomes to mitigate the rising cost of living, increasing population and the normal long dry spell in some parts of the country. This situation creates supply shortages in terms of food availability and accessibility and indirectly creates demand shortages by denying households access to sufficient income.

The major sources of change in food crop production according to Amaza and Maurice (2005) and Panda (2007) include changes in the hectares of various crops cultivated annually, changing production techniques which affect variation in the yields and the productivity of inputs used in the production of various food crops. Others include; type of technology such as variety and agronomic practices of which cropping system is an important aspect of the agronomic practices. In order to improve resource productivity on farms, farmers need to have proper understanding of how to select enterprises for efficient use of resources.

A number of agricultural development institutions and programmes were set up and special programmes launched by successive governments in the country with the aim of improving food supply situation. Most recently is the Agriculture Transformation Agenda; yet significant volume of food is still being imported annually; while agricultural productivity has not appreciated enough to match domestic demand. The share of food import to total import as a proxy for

D. C. Maurice, Department of Agricultural Economics and Extension, Modibbo Adamawa University of Technology, Yola, Adamawa State, Nigeria.

Y. Adamu, Department of Agricultural Economics and Extension, Modibbo Adamawa University of Technology, Yola, Adamawa State, Nigeria.

M. Joseph, Department of Agricultural Economics and Extension, Modibbo Adamawa University of Technology, Yola, Adamawa State, Nigeria. 
agricultural contribution to the nation's food supply shows an average annual share of $13 \%, 9.33 \%$ and $9.15 \%$ respectively for the periods 1994-1999, 20002006 and 2007-2012 (CBN, 2006; 2012).

Productivity growth and resource use efficiency issues are the core elements of sustainable crop production of small-scale farming activities, while inefficient use of production inputs can jeopardize food availability and create scarcity. A better understanding of farmers' production efficiency and how well they are able to produce a given level of output using cost minimization input ratio is important for the sustenance of production system. This is necessary since increased output of food crop and productivity are directly related to production efficiency, arising from optimal input combination given the state of technology. Efficiency gains will have a positive impact on raising farm income of resource poor farmers (Okuneye,1995). Thus, the efficiency with which available resources are used by small-scale farmers becomes a priority subject of investigation in view of the growing gap between demand for and supply of food in the country. This study is therefore undertaken to estimate the cost efficiency of food crop farmers in the study area, describe their socioeconomic characteristics and determine their cropping patterns. This is based on the premise that food availability is a function of food production and considerable effort has been devoted to the analysis of farm level efficiency in developing countries.

\section{Conceptual and Theoretical Framework}

Efficiency of a farm refers to its performance in the utilization of resources at its disposal (Kalirajan, 2007). This performance is either compared with the normative desired level or with that of any other farm. The analysis of efficiency is generally associated with the possibility of farms producing a certain optimal level of output from a given bundle of resources or certain level of output at least cost.

Cost efficiency (otherwise referred to as allocative efficiency) on the other hand refers to the ability of a firm to produce at a given level of output using cost-minimizing input prices (Coelli et al., 2002; Ogundari and Ojo, 2007). The analysis usually assumes that the firm-farm seeks to optimize a cost-minimization objective function subject to resource constraints. Similarly, cost inefficiency arises when resource inputs are used in proportions which do not lead to profit maximization. In this situation the value of the marginal revenue product (MRP) is not equal to that of the marginal cost of that input.

Ogundari and Ojo (2006) examined empirically production efficiency of cassava farms in Osun State of Nigeria using farm level data. The stochastic frontier production and cost function model were used to predict the farm level technical, allocative and economic efficiencies respectively. The result of the analysis revealed that cassava farms in the study area exhibited decreasing positive return to scale, indicating that cassava farmers were efficient in allocating their resources. The predicted mean technical, allocative and economic efficiencies were estimated as $0.903,0.89$ and 0.807 respectively, meaning that technical efficiency appeared to be more significant than allocative efficiency as a source of gain in economic efficiency.
Tanko and Jirgi (2008) investigated economic efficiency among small holder arable crop farmers in Kebbi State, Nigeria using translog stochastic frontier profit function model. The result reveals that mean economic efficiency ranged from 0.21 to 0.95 , with mean economic efficiency of 0.59 . This indicate the existence of a wide efficiency gap between the best economically efficient farmers and that of the average farmers. Farm size and capital inputs were the major factors associated with changes in the output of arable crops; while farmers' specific socio-economic variables, namely; level of education, extension contact and membership of cooperative organization were found to be the significant factors accounting for the variation in efficiency among farmers.

Paudel and Matsuoka (2009) analyzed the cost efficiency of maize production in the Chitwan district, Nepal with a view to predicting economic efficiencies using stochastic frontier cost function. The maximumlikelihood estimates of the parameters revealed that estimated coefficients of cost of tractor, animal power, labour, fertilizer, manure, seed and maize output gave positive coefficients and were statistically significant at $5 \%$ level. The quantitative estimates obtained from the cost function revealed that an average maize farm from the study incurred about $63 \%$ costs above the cost frontier, an indication of inefficiency.

Eze et al. (2010) evaluated resource use efficiency in arable crop production among small holder farmers in Owerri agricultural zone of Imo State, Nigeria. The Result revealed that resources were not efficiently allocated by the farmers. The farmers over-utilized the resources of labour, planting materials, fertilizer capital, and under-utilized land. To attain optimality, the study recommended the need for farmers' education on some fundamental farm management skills.

Zalkuwi et al. (2014) analysed the determinants of cost efficiency in cowpea production in Adamawa State, Nigeria using stochastic cost frontier. The mean allocative efficiency was estimated at 0.66, indicating that farmers operate at $34 \%$ below the cost frontier. The inefficiency models revealed that socio-economic variables, namely; family size, farming experience, gender and extension contact have significantly reduces cost inefficiency among the farmers.

\section{METHODOLOGY \\ i. Study Area}

Adamawa State is located in the North East part of Nigeria between latitude $7.0^{\circ} \mathrm{N}$ and $11.0^{\circ} \mathrm{N}$ of the equator and longitude $11.0^{\circ} \mathrm{E}$ and $14.0^{\circ} \mathrm{E}$ of the Greenwich meridian (Adebayo, 1999). The State shares common boundary with Taraba State in the South and West, Gombe State in its Northwest and Borno State to the North. It has an international boundary with the Cameroun Republic along its eastern border. The State covers a land mass area of about $38,741 \mathrm{~km}^{2}$ and is divided into 21 Local Government areas. The State has population of $3,161,374$ people comprising of $1,580,333$ males and 1,581,041 females (NPC, 2006). As opposed to a national annual population growth rate of $3.2 \%$, the population of Adamawa State is growing at $2.8 \%$ per annum (Adamawa State MDGs Report, 2006). By 2015, the State is expected to have 4,067,411 inhabitants according to projection. 
The State has a tropical climate marked by dry and rainy seasons. The rainy season commences in April and ends in late October. The wettest months are August and September. The mean annual rainfall pattern shows that the amounts range from $700 \mathrm{~mm}$ in the north-west part to $1600 \mathrm{~mm}$ in the southern part (Adebayo, 1999). The mean annual rainfall is less than $1000 \mathrm{~mm}$ in the central and north-western part of the State. On the other hand, the north-eastern strip and the southern part have over $1000 \mathrm{~mm}$ of rainfall.

The major economic activity of the inhabitants is agriculture (farming, fishing and cattle rearing). Some of the agricultural crops of importance are cereals, roots and legumes supplemented by few planted trees. The main food crops grown are maize, sorghum, millet, rice, cowpea, groundnut, sweet potato, yam and cassava. The farming system employed is either mono-cropping or mixed cropping. Non-farm economic activities include trading, blacksmithing, fishing and animal husbandry among others.

\section{ii. Sampling Technique}

Multi-stage random sampling was employed in the selection of respondents in eight out of the twenty one Local Government Areas of the State. In the first stage, two Local Government Areas were randomly selected in each of the four Agricultural Development Programme (ADP) zones of the State namely; Mubi North and Madagali Local Governments (Zone I), Gombi and Girei Local Governments (Zone II), Mayo-Belwa and
Fufore Local Governments (Zone III), and Guyuk and Ganye Local Governments (Zone IV) due to their prominence in food crop production. Each of the State ADP zone has five LGAs except Zone III that has six. In the second stage three villages were randomly sampled in each of the selected Local Government Areas, giving a total of 24 sampled villages. Third stage sampling involved the random selection of 360 food crop farmers in the 24 sampled villages from the existing sampling frame (Appendix 1). Primary data was mainly used for the study and collected through structured questionnaire administration to food crop farmers in the sampled villages with the assistance of trained ADP staff. Data collected were for 2009 and 2010 cropping seasons.

\section{iii. Analytical Framework}

Descriptive statistics involving the use of frequency distributions, percentages and means was used in describing the socio-economic characteristics of the respondents and their cropping systems as well as inferential statistics involving the use of stochastic cost function.

\section{iv. Model Specification}

Following Ogundari and Ojo (2007) stochastic cost function was employed to estimate the firm-level cost efficiency of the farmers in the study area. The explicit Cobb-Douglas cost function for food crop farmers in Adamawa State is specified thus;

$$
\begin{aligned}
& \ln C_{i j}=\beta_{0}+\beta_{1} \ln P_{1 i j}+\beta_{2} \ln P_{2 i j}+\beta_{3} \ln P_{3 i j}+\beta_{4} \ln P_{4 i j}+\beta_{5} \ln P_{5 i j}+ \\
& \beta_{6} \ln P_{6 i j}+V_{i j}-U_{i j}
\end{aligned}
$$

Where:

Subscript ij refers to the $j^{\text {th }}$ observation of the $i^{\text {th }}$ farmer.

Ln = Logarithm to base e

$\mathrm{C}_{\mathrm{ij}} \quad=$ Total production cost $(\mathrm{A} / \mathrm{ha})$ of the $\mathrm{i}^{\text {th }}$ farmer

$\mathrm{P}_{1} \quad=$ Expenses on land $(\mathrm{N})$

$\mathrm{P}_{2} \quad=$ Cost of Family labour $(\mathrm{A} / \mathrm{ha})$

$\mathrm{P}_{3} \quad=$ Cost of Hired labour ( $\left.\mathrm{N} / \mathrm{ha}\right)$

$\mathrm{P}_{4} \quad=$ Cost of agrochemicals $(\mathrm{N} / \mathrm{ha})$

$\mathrm{P}_{5} \quad=$ Cost of inorganic fertilizer $(\mathrm{A} / \mathrm{ha})$

$\mathrm{P}_{6} \quad=$ Cost of seeds $(\AA / h a)$

i). Total production cost: This measures the total cost of production per hectare in the last cropping season by the farmers. Since fixed cost of production is negligible in the short-run, the study used only variable cost of production per hectare as a proxy for total production cost.

ii). Expenses on land: This is measured as the amount of money or its equivalent paid as rent for the use of land during the last cropping season. Where produce are given, the study used the value of $10 \%$ of the total output as a proxy for expenses on land.

iii). Cost of family labour: This is measured as the amount of money which would have been paid for labour if it is hired during farm operations. It is measured in naira per hectare.

iv). Cost of hired labour: This is the amount of money paid for the hire of labour during farm operations. It is measured in naira per hectare.

v). Cost of agrochemicals: This is the total expenses on herbicides and pesticides incurred by the farmer during the last cropping season. It is measured in naira per hectare.

vi). Cost of inorganic fertilizers: This is the total expenses on inorganic fertilizers such as NPK, Urea incurred by the farmer during the last cropping season. It is measured in naira per hectare.

vii). Cost of seed: This is the total expenses on seed incurred by the farmer during the last cropping season. It is measured in naira per hectare.

It is assumed that the cost inefficiency effects are independently distributed and $U_{i}$ arises by truncation (at zero) of the normal distribution with mean, $\mu$ ij and variance $\delta^{2}$, where $\mu$ ij is defined by: 
$\mu_{i j}=\delta_{0}+\delta_{1} Z_{1 i j}+\delta_{2} Z_{2 i j}+\delta_{3} Z_{3 i j}+\delta_{4} Z_{4 i j}+\delta_{5} Z_{5 i j}+\delta_{6} Z_{6 i j}+\delta_{7} Z_{7 i j}$

Where:

$\mu_{\mathrm{ij}} \quad=$ Cost inefficiency of the $\mathrm{i}^{\text {th }}$ farmer

$Z_{1} \quad=$ Denotes years of farming experience

$Z_{2} \quad=$ Represent years of formal education

$Z_{3} \quad=$ Extension contact (number of meetings)

$Z_{4} \quad=$ Household size (number)

$Z_{5} \quad=$ Primary occupation (dummy, where one indicated farming and zero otherwise)

$Z_{6} \quad=$ Crop diversification (dummy, where one indicated mixed cropping and zero Sole cropping)

$Z_{7} \quad=$ Credit availability (dummy, where one indicated those that accessed credit and zero otherwise)

\section{RESULTS AND DISCUSSION}

The socio-economic characteristics of the respondents are presented in Table 1 . The result shows that women farmers dominated (57.22\%) food crop production in the State thus, agreeing with the findings by Sigot (1995) and Umoh (2006) who reported that women constitute about $60-70 \%$ of African agricultural workforce and produce an estimated $70 \%$ of total food production. Their age distribution shows that majority $(55 \%)$ were not more than 40 years of age, while only about $15 \%$ were over 50 years of age. Their mean age was 41 years, an indication that they are relatively young and physically active, and this has direct bearing on the availability of able-bodied manpower for primary production.

Majority (about 68\%) of food crop farmers in the State had household size of 1-9 persons, with a mean household size of 8 persons. Respondents' educational levels revealed that about $88 \%$ of the respondents had some form of formal education. Thus, literacy level is high among the respondents and this could have implication for agricultural production in the area. About $78 \%$ of the respondents had farming experience of more than 11 years. The mean of farming experience is about 19 years indicating that most of the respondents were well experienced in food crop production.

The distribution of farm sizes of the respondents shows that majority (about $65 \%$ ) of them cultivated up to 2 hectares of farm land, while only about $6 \%$ cultivated 6 hectares and above. The mean farm size of the respondents is about 2 hectares indicating that food crop production in the State is undertaken on a small scale.

Table 1: Socio-economic characteristics of the respondents

\begin{tabular}{lll}
\hline Sex & Frequency & Percentage (\%) \\
Male & 154 & 42.78 \\
Female & 206 & 57.22 \\
Age Interval (years) & Frequency & Percentage (\%) \\
$\leq 30$ & 62 & 17.22 \\
$31-40$ & 136 & 37.78 \\
$41-50$ & 109 & 30.28 \\
$51-60$ & 42 & 11.67 \\
$>60$ & 11 & 3.05 \\
Mean & 40.99 years & \\
Household size & Frequency & Percentage (\%) \\
$1-4$ & 59 & 16.38 \\
$5-9$ & 186 & 51.67 \\
$10-14$ & 86 & 23.89 \\
$>14$ & 29 & 8.06 \\
Mean & 8.35 & \\
Educational level & Frequency & Percentage (\%) \\
No formal education & 43 & 11.94 \\
Primary education & 48 & 13.33 \\
Secondary education & 166 & 46.11 \\
Tertiary education & 103 & 28.61 \\
Farming experience (years) & Frequency & Percentage (\%) \\
$1-5$ & 14 & 3.89 \\
$6-10$ & 66 & 18.33 \\
$11-15$ & 86 & 23.89 \\
$16-20$ & 72 & 20.0 \\
$>20$ & 122 & 33.89 \\
Mean & 18.58 years & \\
Farm size (ha) & Frequency & Percentage (\%) \\
$\leq 2.0$ & 234 & 65.00 \\
$2.1-3.9$ & 65 & 18.06 \\
$4.0-5.9$ & 38 & 10.56 \\
$\geq 6.0$ & 23 & 6.38 \\
Mean & 2.12 ha & \\
\hline & 5010 & \\
& 56 & 2010 \\
\hline
\end{tabular}




\section{Cropping systems of the respondents}

Cropping systems are the yearly sequence and spatial arrangement of crops on a given area. The objective of any cropping system is efficient allocation of all resources (Panda, 2007). The distribution of the cropping systems of food crop farmers as presented in Table 2 has revealed eleven (11) cropping systems. Sole cropping accounted for $46.67 \%$ of the cropping systems and $45.89 \%$ of the total hectarage allocation, while mixed cropping system accounted for $53.33 \%$ of the cropping systems and $54.11 \%$ of the total hectarage allocation. Maize-based enterprise accounted for $48.07 \%$ of the cropping systems and $55.3 \%$ of the total hectarage allocation, and is attributed to maize being the staple food of most households in the State.

The distribution of the cropping systems have also revealed that maize/cowpea, sole maize, sole rice and maize/sorghum enterprises accounted for $17.74 \%$, $16.73 \%, 15.48 \%$ and $11.18 \%$ respectively of the total hectarage allocated to food crop production in the study area. By implication, it means that these four cropping systems accounted for majority (about $61 \%$ ) of the total crop area allocated to food crop production. All these crops are staple foods in the State. Sorghum/cowpea, maize/sorghum/cowpea and sole cowpea cropping systems accounted for only $24 \%$ of the total area allocated to food crop production. However, maize/millet/cowpea and rice/maize cropping systems were practiced by only few farmers and they accounted for only about $3 \%$ of the total hectarage allocation to food crop in the study area.

The farm size of all the enterprises ranged from 1.09-3.45ha, an indication that food crop production in the area is undertaken on a small scale. The total hectarage allocation to food crop production among the respondents was estimated to be 762.25ha., with an average farm size of $2.12 \mathrm{ha}$.

Table 2: Distribution of Respondents by Cropping Systems and their farm sizes (ha)

\begin{tabular}{|c|c|c|c|c|c|}
\hline Cropping systems & $\begin{array}{l}\text { No. of } \\
\text { respondents }\end{array}$ & $\%$ & Total area (ha) & $\%$ & $\begin{array}{ll}\text { Average } & \text { farm } \\
\text { size (ha) } & \\
\end{array}$ \\
\hline Sole maize & 52 & 12.85 & 127.50 & 16.73 & 1.88 \\
\hline Sole cowpea & 34 & 8.40 & 54.0 & 7.08 & 1.59 \\
\hline Sole rice & 61 & 15.06 & 118.0 & 15.48 & 1.93 \\
\hline Sole groundnut & 40 & 9.88 & 50.0 & 6.60 & 1.09 \\
\hline Maize/cowpea & 83 & 20.49 & 135.25 & 17.74 & 1.63 \\
\hline Maize/sorghum & 39 & 9.63 & 85.25 & 11.18 & 2.19 \\
\hline Maize/sorghum/cowpea & 30 & 7.41 & 63.0 & 8.27 & 2.10 \\
\hline Maize/millet/cowpea & 10 & 2.47 & 10.50 & 1.38 & 1.05 \\
\hline Sorghum/cowpea & 32 & 7.90 & 67.0 & 8.79 & 2.09 \\
\hline Millet/ cowpea & 06 & 1.48 & 11.50 & 1.514 & 1.92 \\
\hline Rice/maize & 18 & 4.44 & 40.25 & 5.28 & 2.24 \\
\hline Total & $405^{*}$ & 100.0 & 762.25 & 100.0 & \\
\hline
\end{tabular}

Source: Field Survey, 2009 and 2010

*Multiple responses

\section{Allocative Efficiency}

The maximum likelihood estimates of the parameters of the stochastic cost frontier model used in estimating allocative efficiency are presented in Table 3. All parameter estimates have the expected sign, where cost of land $\left(P_{1}\right)$, cost of hired labour $\left(P_{3}\right)$, cost of agrochemicals $\left(P_{4}\right)$ and cost of inorganic fertilizer $\left(P_{5}\right)$ are statistically significant, meaning that these factors are important determinants of total cost associated with food crop production in the study area. The cost elasticities with respect to all input variables used in the production analysis are positive, implying that an increase in the costs of land, hired labour, agrochemicals and inorganic fertilizers increases total production cost. That is, $1 \%$ increase in the cost of hired labour, cost of agro-chemicals, cost of land and cost of inorganic fertilizers will increase total production cost by approximately $0.25 \%, 0.17 \%, 0.015 \%$ and $0.37 \%$ respectively.

The estimated gamma parameter $(\mathrm{\gamma})$ of 0.680 is highly significant at $1 \%$ level, indicating that $68 \%$ of the variation in the total cost of production among the sampled farmers is due to differences in their cost efficiencies. Sigma squared $\left(\sigma^{2}\right)$ on the other hand is 0.825 and statistically significant at $1 \%$ level indicating correctness of fit of the model as assumed for the composite error term.

The return to scale is 0.928 , indicating decreasing returns to scale. This implies that food crop farmers in the study area are operating in the rational stage of the production surface (stage II) where additional input add less to total output than the preceding unit. Adjustments in the use of inputs can be made at this stage so that farmers could produce at the point of economic optimum which guarantees profit maximization.

The estimated coefficient of the explanatory variables in the inefficiency cost model shows that all the coefficients have the expected signs. Extension contact $\left(Z_{3}\right)$, crop diversification $\left(Z_{6}\right)$ and credit availability $\left(Z_{7}\right)$ are statistically significant and positively related to cost efficiency among the sampled farmers because a negative coefficient implies decrease in cost inefficiency and vice-versa. 
The coefficient of extension variable is estimated to be negative and statistically significant at $5 \%$ level, indicating that increased extension services to farmers tend to decrease cost inefficiency in food crop production. Advisory services of extension assist farmers in making sound production and marketing decisions which helps in enhancing cost efficiency.

The coefficient of credit availability is estimated to be negative and statistically significant at $1 \%$ level, implying that credit availability among farmers decreases cost inefficiency in food crop production. Borrowed funds used in agricultural production is expected to bring about efficient utilization of such funds so that farmers could realize the output that would sufficiently offset the credit facility and still be left with marketable surplus.
The crop diversification variable in the model is negative and statistically significant at 5\% level, implying that crop diversification increases cost efficiency in food crop production. Similarly, as crop diversification decreases and fewer crops are grown, cost inefficiency increases. The practice of mixed cropping enables various crop combinations to use some resource inputs jointly such as labour which otherwise would be allocated to only one crop if produced solely. Cost of production in this situation is expected to be lower under mixed cropping than under sole cropping. The implication is that crop diversification is associated with higher relative allocative efficiency in the use of resource inputs.

Table 3: Maximum likelihood estimates of parameters of stochastic cost function

\begin{tabular}{|c|c|c|c|c|}
\hline Variable & & Parameter & Coefficient & t- ratio \\
\hline \multicolumn{5}{|l|}{ Cost factors } \\
\hline Constant & & $\beta_{0}$ & 2.405 & $18.416^{*}$ \\
\hline Cost of land $\left(P_{1}\right)$ & & $\beta_{1}$ & 0.015 & $7.249^{*}$ \\
\hline Cost of Family labour $\left(\mathrm{P}_{2}\right)$ & & $\beta_{2}$ & 0.115 & 0.144 \\
\hline Cost of Hired labour $\left(\mathrm{P}_{3}\right)$ & & $\beta_{3}$ & 0.245 & $2.033^{\star *}$ \\
\hline Cost of Agrochemicals $\left(P_{4}\right)$ & & $\beta_{4}$ & 0.170 & $7.554^{*}$ \\
\hline Cost of inorganic fertilizer $\left(\mathrm{P}_{5}\right)$ & & $\beta_{5}$ & 0.136 & $2.386^{* *}$ \\
\hline Cost of Seed $\left(P_{6}\right)$ & & $\beta_{6}$ & 0.247 & 0.223 \\
\hline Returns to scale $\left(\sum\right.$ of $\left.\beta_{1}-\beta_{6}\right)$ & 0.928 & & & \\
\hline \multicolumn{5}{|l|}{ Inefficiency effects } \\
\hline Constant & & $\delta_{0}$ & -0.026 & $-7.3309^{*}$ \\
\hline Farming experience $\left(Z_{1}\right)$ & & $\delta_{1}$ & -0.462 & -1.4241 \\
\hline Education $\left(Z_{2}\right)$ & & $\delta_{2}$ & -0.061 & -1.6257 \\
\hline Extension contact $\left(\mathrm{Z}_{3}\right)$ & & $\delta_{3}$ & -0.473 & $-2.6414^{* *}$ \\
\hline Household size $\left(Z_{4}\right)$ & & $\delta_{4}$ & -0.026 & -0.0298 \\
\hline Primary occupation $\left(Z_{5}\right)$ & & $\delta_{5}$ & -0.021 & -0.0217 \\
\hline Crop diversification $(6)$ & & $\delta_{6}$ & -0.664 & $-2.2426^{* *}$ \\
\hline Credit availability $\left(Z_{7}\right)$ & & $\delta_{7}$ & -1.132 & $-10.5308^{*}$ \\
\hline \multicolumn{5}{|l|}{ Diagnostic statistics } \\
\hline Likelihood ratio & & & 3.343 & \\
\hline Sigma-squared & & $\left(\sigma^{2}\right)$ & 0.825 & $44.5851^{*}$ \\
\hline Gamma & & (y) & 0.680 & $3.8169^{*}$ \\
\hline
\end{tabular}

Source: Computer output from Frontier 4.1

* Significant at $1 \%$ level; $\quad$ ** Significant at $5 \%$ level

The distribution of farmers' allocative efficiency indices derived from the analysis of the stochastic cost function is presented in Table 4. The allocative efficiency of the sampled farmers ranged from 0.18 to 0.98 . The mean allocative efficiency is estimated to be 0.84 , meaning that an average farmer in the study area has the scope for increasing allocative efficiency by $16 \%$ in the shortrun under the existing technology. This would enable the average farmer equate the marginal value product (MVP) of the inputs to the marginal cost of the inputs thereby increasing food crop output and improving farm income. Only $2.5 \%$ of the respondents had allocative efficiency of $50 \%$ and below, while about $3 \%$ had allocative efficiency of $51-70 \%$. The majority of the respondents (about 73\%) had allocative efficiency of 71$90 \%$, while only about $18 \%$ had allocative efficiency of $91-100 \%$. This result shows that food crop farmers in the study area are fairly efficient in allocation of resources in producing a given level of output using cost minimizing input ratios which reflects the farmers' tendency to minimize resource wastage associated with production process. 
Table 4: Allocative efficiency indices of food crop farmers

\begin{tabular}{lll}
\hline Efficiency level & Frequency & Percentage \\
\hline$\leq 0.40$ & 6 & 1.67 \\
$0.41-0.50$ & 3 & 0.83 \\
$0.51-0.60$ & 6 & 1.67 \\
$0.61-0.70$ & 5 & 1.39 \\
$0.71-0.80$ & 63 & 17.50 \\
$0.81-0.90$ & 212 & 58.89 \\
$0.91-1.00$ & 65 & 18.06 \\
Total & 360 & 100.0 \\
Mean $\quad 0.84$ & & \\
Minimum 0.18 & & \\
Maximum 0.98 & & \\
\hline
\end{tabular}

Source: Field survey, 2009 and 2010

\section{CONCLUSION}

Food crop production in Adamawa State is mostly undertaken by the female gender who are mostly full-time farmers and well experienced in food crop production. They cultivated an average farm size of about 2 hectares and utilized personal savings in agricultural production, an indication that agricultural production is still at subsistence level.

Mixed cropping dominated the cropping systems where maize-based enterprise accounted for $48 \%$ of the cropping systems and about $55 \%$ of the total hectarage allocation to food crop production. Maize-based enterprise accounted for $48.07 \%$ of the cropping systems and $55.3 \%$ of the total hectare allocation, and is attributed to maize being the staple food of most households. Cowpea is often intercropped with maize, sorghum and millet in the cropping systems due largely to the importance of the crop in meeting the dietary protein requirement of many rural households.

The maximum likelihood estimate of the stochastic frontier cost function revealed that cost of land, cost of hired labour, cost of agrochemicals and cost of inorganic fertilizers contributed significantly and positively to total cost of production. The allocative efficiency index ranged from $0.18-0.98$, with a mean of 0.84 an indication that food crop farmers in the study area are fairly efficient in resource allocation for food crop production. The farmers however have scope for increasing allocative efficiency by $16 \%$ given the existing technology.

\section{RECOMMENDATIONS}

Based on the findings of this research, the following recommendations are proffered.

1. To reduce the negative consequences of inefficient use of resources, farmers should be educated by government and non-governmental agencies on fundamental farm management skills which will enable them to plan, evaluate and appraise their farm business activities. There is also the need for farmers to acquire basic education since education positively influences efficiency.

2. Effective extension programmes that will educate farmers on efficient allocation of production resources are points upon which the various smallholder development programmes initiated by the government should be built. To this end, the extension arm of the ADP should be resuscitated and strengthened through adequate funding by the government instead of introducing new schemes and programmes which duplicates tasks.

3. Government and donor agencies should encourage and support crop breeding researches so as to raise the productivity of existing seeds. Also, the outcome of such researches should get to the farmers instead of remaining in the libraries and archives.

\section{REFERENCES}

Adamawa State MDGs report., 2006. Adamawa State Millennium Development Goals Report, UNDP.

Adebayo, A. A., 1999. Climate I and II. Adebayo, A.A. and Tukur, A.L (eds.), Adamawa State in Map. Department of Geography, Federal University of Technology, Yola. Paraclete publishers, Yola. 20-26.

Agbonlahor, M. U., 1999. Economics of mixed farming: A case of poultry -arable crop farming in Edo State, Nigeria. Unpublished Master's thesis, University of Agriculture, Abeokuta, Nigeria.

Amaza, P.S. and Maurice, D.C. (2005). "Identification of factors that influence technical efficiency in ricebased production systems in Nigeria". P. Kormawa and A.A. Toure (eds.) Proceedings of a workshop on Rice Policy and Food Security in Sub-Saharan Africa held in Cotonou, Benin, $7^{\text {th }}$ $-9^{\text {th }}$ November. Pp.70- 81

CBN., 2006. Central Bank of Nigeria Annual Report and Statement of Account for the year ended $31^{\text {st }}$ December. A Publication of the Central Bank of Nigeria.

CBN., 2012. Central Bank of Nigeria Statistical Bulletin, 23 ,

Coelli, T., Rahman, S and Thirtle, C., 2002. Technical, Allocative, Cost and Scale Efficiencies in Bangladesh rice cultivation: A non-parametric 
approach. Journal of Agricultural Economics $53,607-626$.

Eze, C. C., Amanze, B and Nwankwo, O., 2010. Resource Use Efficiency in Arable Crop Production among Smallholder Farmers in Owerri Agricultural Zone of Imo State, Nigeria. $\begin{array}{lll}\text { Researcher } \quad 2, \quad(5): & 14-20\end{array}$ http://www.sciencepub.net/researcher.

Kalirajan, K., 2007. Technical Efficiency of Major Food and Cash Crops in Karnataka, India. Crawford. 2, (1):

Maurice, D. C., Onu, J. I., Adebayo, E. F and Garba, A., 2013. Optimal Production Plan and Resource Allocation among Small-scale Farmers in some selected Local Government Areas of Adamawa State, Nigeria. Journal of Technology and Education Research (JOTER), 6, (2), 47-57.

NPC., 2006. National Population Census, Federal Republic of Nigeria Official Gazette, 94, Lagos

Ogundari, K., Ojo, S. O and Ajibefun, I. A., 2006. Economics of Scale and Cost Efficiency in Small Scale Maize Production: Empirical Evidence From Nigeria. Journal of Social Science 13, (2), 131-136.

Ogundari, K. and Ojo, S.O., 2007. Economic Efficiency of Small Scale Food Crop Production in Nigeria: A Stochastic Frontier Approach. Journal of Social Science. 14, (2): 123-130.

Okuneye, P. A., 1995. Nigeria Agriculture on the run. University of Agriculture, Abeokuta Inaugural Lecture Series, Wallingford, England. 26-48.

Panda, S. C., 2007. Farm Management and Agricultural Marketing. Kalyani Publishers, India. 26-80.
Paudel, $P$ and Matsuoka, A., 2009. Cost Efficiency Estimates of Maize Production in Nepal: A case study of the Chitwan District. Journal of Agricultural Economics-CZECH. 55, (3): 139148.

Sani, M. H and Haruna, U., 2010. Farm Planning Model for Sustainable Vegetable Crop Production in the Eastern Part of Kogi State, Nigeria. Nigeria Journal of Agronomy. 9, 17-22.

Sigot, A. J., 1995. Discourse on Gender and Natural Resource Management. In Sigot, A.J., Thrupp, L.A. and Green, J (eds.), Towards Common Ground: Gender and Natural Resource Management in Africa. ACTS Press, Nairobi, Kenya.

Tanko, L and Jirgi, A. J., 2008. Economic Efficiency among Smallholder Arable Crop Farmers in Kebbi State, Nigeria. Continental Journal of Agricultural Economics. 2, 14-22.

Umoh, S. G., 2006. Resource Use Efficiency in Urban Farming: An application of Stochastic Frontier Production Function. International Journal of Agriculture and Biology. 8, (1): 38-44.

Zalkuwi, J., Maurice, D. C and Yusuf, C., 2014. Determinant of Cost Efficiency in Cowpea Production: A Case Study of Adamawa State, Nigeria. International Journal of Science and Research, 3, (9): 407-410. 
APPENDIX 1

Distribution of sample in the 8 Local Government Areas

\begin{tabular}{|c|c|c|c|}
\hline AD.ADP Zones & LGAs & Villages & No. of Sample \\
\hline \multirow[t]{8}{*}{ Zone I } & Mubi North & Muva & 20 \\
\hline & & Bahuli & 17 \\
\hline & & Lira & 15 \\
\hline & & Total & 52 \\
\hline & Madagali & Wurogayandi & 15 \\
\hline & & Duhu & 30 \\
\hline & & Dar & 20 \\
\hline & & Total & 65 \\
\hline \multirow[t]{8}{*}{ Zone II } & Gombi & Gadamaisaje & 10 \\
\hline & & Bebe & 10 \\
\hline & & Parijo & 13 \\
\hline & & Total & 33 \\
\hline & Girei & Dakri Bobbo & 15 \\
\hline & & Jabbi-Lamba & 15 \\
\hline & & Njerenga & 15 \\
\hline & & Total & 45 \\
\hline \multirow[t]{8}{*}{ Zone III } & Mayo-Belwa & Sangere & 15 \\
\hline & & Sindigawo & 15 \\
\hline & & Yolde Gubudo & 15 \\
\hline & & Total & 45 \\
\hline & Fufore & Wuro-Mallum & 10 \\
\hline & & Dulo Bwatiye & 15 \\
\hline & & Muninga & 15 \\
\hline & & Total & 40 \\
\hline \multirow[t]{8}{*}{ Zone IV } & Guyuk & Pondiwe & 10 \\
\hline & & Lakumna & 13 \\
\hline & & Bodeno & 17 \\
\hline & & Total & 40 \\
\hline & Demsa & Dwam Sakato & 10 \\
\hline & & Bolon & 15 \\
\hline & & Dong & 15 \\
\hline & & Total & 40 \\
\hline \multicolumn{2}{|c|}{ Total No. of respondents } & & 360 \\
\hline
\end{tabular}

Source: Field Survey, 2009 and 2010 